Article

\title{
Synthesis, Structure and Magnetic and Electrochmical Properties of Tetrakis(benzamidato)diruthenium(II,III) Tetrafluoroborate
}

\author{
Makoto Handa ${ }^{1, *}$, Natsumi Yano ${ }^{1}$, Airi Okuno ${ }^{1}$, Hiroki Nakai ${ }^{1}$, Minoru Mitsumi ${ }^{2}$, \\ Masahiro Mikuriya 3 (iD) and Yusuke Kataoka ${ }^{1, *}$ \\ 1 Department of Chemistry, Interdisciplinary Graduate School of Science and Engineering, \\ Shimane University, 1060 Nishikawatsu, Matsue 690-8504, Japan; s179802@matsu.shimane-u.ac.jp (N.Y.); \\ s141027@matsu.shimane-u.ac.jp (A.O.); s131081@matsu.shimane-u.ac.jp (H.N.) \\ 2 Department of Chemistry, Faculty of Science, Okayama University of Science, 1-1 Ridaicho, Kita-Ku, \\ Okayama 700-0005, Japan; mitsumi@chem.ous.ac.jp \\ 3 Department of Applied Chemistry for Environment, School of Science and Technology, Kwansei Gakuin \\ University, 2-1 Gakuen, Sanda 669-1337, Japan; junpei@kwansei.ac.jp \\ * Correspondence: handam@riko.shimane-u.ac.jp (M.H.); kataoka@riko.shimane-u.ac.jp (Y.K.); \\ Tel.: +81-852-32-6418 (M.H.); +81-852-32-6413 (Y.K.)
}

Received: 15 April 2018; Accepted: 27 April 2018; Published: 1 May 2018

\begin{abstract}
A lantern-type diruthenium(II,III) complex $\left[\mathrm{Ru}_{2}(\mathrm{HNOCPh})_{4}\left(\mathrm{BF}_{4}\right)\left(\mathrm{H}_{2} \mathrm{O}\right)\right]$ was prepared from $\left[\mathrm{Ru}_{2}(\mathrm{HNOCPh})_{4} \mathrm{Cl}\right]_{n}$ by removal of the axial chlorido-bridge using $\mathrm{AgBF}_{4}$ in THF. The room temperature magnetic moment (per $\mathrm{Ru}_{2}{ }^{5+}$ unit) of $\left[\mathrm{Ru}_{2}(\mathrm{HNOCPh})_{4}\left(\mathrm{BF}_{4}\right)\left(\mathrm{H}_{2} \mathrm{O}\right)\right]$ is $3.84 \mu_{\mathrm{B}}$, which is similar to that $\left(4.15 \mu_{\mathrm{B}}\right)$ of $\left[\mathrm{Ru}_{2}(\mathrm{HNOCPh})_{4} \mathrm{Cl}\right]_{n}$, for which magnetic measurement was newly performed in this study. These results indicate that both of the complexes have a spin state of $S=3 / 2$, although temperature-variable (VT) magnetic moments (2-300 K) showed that considerable antiferromagnetic interaction $\left(z J=-2.8 \mathrm{~cm}^{-1}\right)$ exists through the axial chlorido-bridge for $\left[\mathrm{Ru}_{2}(\mathrm{HNOCPh})_{4} \mathrm{Cl}\right]_{n}$, but such a large interaction $\left(z J=-0.08 \mathrm{~cm}^{-1}\right)$ does not exist for $\left[\mathrm{Ru}_{2}(\mathrm{HNOCPh})_{4}\left(\mathrm{BF}_{4}\right)\left(\mathrm{H}_{2} \mathrm{O}\right)\right]$, where the large zero-field splitting $D=61 \mathrm{~cm}^{-1}$ is operative for both complexes, like other lantern-type diruthenium(II,III) complexes. The X-ray single-crystal structure analysis of $\left[\mathrm{Ru}_{2}(\mathrm{HNOCPh})_{4}\left(\mathrm{BF}_{4}\right)\left(\mathrm{H}_{2} \mathrm{O}\right)\right] \cdot 2$ (acetone) showed that the axial positions of the complex were occupied by a fluorine atom of the $\mathrm{BF}_{4}{ }^{-}$ion and an oxygen atom of the water molecule, with distances of $\mathrm{Ru}-\mathrm{F}_{\mathrm{ax}}=2.3265(19) \AA$ and $\mathrm{Ru}-\mathrm{O}_{\mathrm{ax}}=2.280(2) \AA$, respectively. The $\mathrm{Ru}-\mathrm{Ru}$ bond distance was 2.2793(4) $\AA$, which is shorter than those (2.295(2) and 2.290(2) $\AA$ ) reported for $\left[\mathrm{Ru}_{2}(\mathrm{HNOCPh})_{4} \mathrm{Cl}\right]_{n}$. The quartet ground states $(S=3 / 2)$ were reasonably interpreted for $\left[\mathrm{Ru}_{2}(\mathrm{HNOCPh})_{4}\left(\mathrm{BF}_{4}\right)\left(\mathrm{H}_{2} \mathrm{O}\right)\right]$ and $\left[\mathrm{Ru}_{2}(\mathrm{HNOCPh})_{4} \mathrm{Cl}\right]_{n}$, as well as the theoretically modeled complex cation $\left[\mathrm{Ru}_{2}(\mathrm{HNOCPh})_{4}\right]^{+}$, by DFT calculation results. $\mathrm{A} \mathrm{Ru}_{2}{ }^{6+} / \mathrm{Ru}_{2}{ }^{5+}$ redox couple was observed at $1.12 \mathrm{~V}$ (vs. SCE) for $\left[\mathrm{Ru}_{2}(\mathrm{HNOCPh})_{4}\left(\mathrm{BF}_{4}\right)\left(\mathrm{H}_{2} \mathrm{O}\right)\right]$ in dichloromethane containing $\mathrm{Bu}_{4} \mathrm{NPF}_{6}$ as electrolyte.
\end{abstract}

Keywords: lantern-type diruthenium(II,III) complex; amidato-bridge; crystal structure; magnetic properties; quartet ground state; electrochemical properties; DFT calculation

\section{Introduction}

There has been much interest directed towards lantern-type dinuclear complexes, due to the unique properties resulting from the meta-metal interactions within the dinuclear molecules $[1,2]$. In the cases of tetracarboxylatodiruthenium(II,III) complexes $\left[\mathrm{Ru}_{2}\left(\mathrm{O}_{2} \mathrm{CR}\right)_{4} \mathrm{X}\right]$, it is well known that the electronic configuration is $\sigma^{2} \pi^{4} \delta^{2}\left(\delta^{*} \pi^{*}\right)^{3}$ [1-5]. The spin state of $S=3 / 2$ has also been thought to be common for the diruthenium(II,III) complex with diarylformamidinate $\left(\mathrm{DArF}^{-}\right)$bridges having 
an $N, N$-donor set, the chemical structure of which is shown in Scheme 1a [1,6-8], although a spin cross-over behavior was reported for $\left[\mathrm{Ru}_{2}(\mathrm{DArF})_{4} \mathrm{Cl}\right](\mathrm{Ar}=p$-methoxyphenyl group) [9]. Recently, $\left[\mathrm{Ru}_{2}(\mathrm{DArF})_{4}\right] \mathrm{BF}_{4}(\mathrm{Ar}=p$-methoxyphenyl or $m$-methoxyphenyl group) obtained by the removal of the axial chloride ion from $\left[\mathrm{Ru}_{2}(\mathrm{DArF})_{4} \mathrm{Cl}\right]$ was reported to show a singlet ground state $(S=1 / 2)[10]$. Such spin state change from $S=3 / 2$ to $S=1 / 2$ has not been reported on the removal of the axial halogenide ligand from $\left[\mathrm{Ru}_{2}\left(\mathrm{O}_{2} \mathrm{CR}\right)_{4} \mathrm{X}\right]$. Amidate ions with an $\mathrm{N}, \mathrm{O}$-donor set have also been known to work as a dinucleating bridging ligand to give a lantern-type structure [11-21]. One of the amidates is benzamidate $\left(\mathrm{PhCONH}^{-}\right)$, the chemical structure of which is shown in Scheme $1 \mathrm{~b}$.

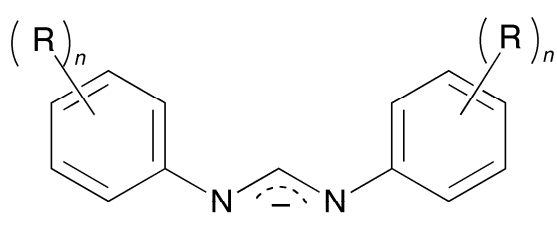

(a) DArF-

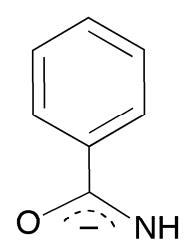

(b) $\mathrm{PhCONH}^{-}$

Scheme 1. Chemical structures of diarylformamidinate $\left(\mathrm{DArF}^{-}\right)$and benzamidate $\left(\mathrm{PhCONH}^{-}\right)$ligands.

In 1985, the zigzag chain structure of $\left[\mathrm{Ru}_{2}(\mathrm{HNOCPh})_{4} \mathrm{Cl}\right]_{n}$ was determined using X-ray crystal structure analysis by Chakravarty and Cotton, although the magnetic properties were not reported in spite of the interest in magnetic interaction through the axial chlorido-bridge between the spins in lantern-type $\mathrm{Ru}_{2}{ }^{5+}$ dinuclear cores [15]. In order to investigate the spin state of the $\mathrm{Ru}_{2}{ }^{5+}$ core and the magnetic interaction through the chlorido-bridge, we newly synthesized a tetrafluoroborate complex $\mathrm{Ru}_{2}(\mathrm{HNOCPh})_{4} \mathrm{BF}_{4} \cdot \mathrm{H}_{2} \mathrm{O}$ by removing the axial chlorido-bridge of $\left[\mathrm{Ru}_{2}(\mathrm{HNOCPh})_{4} \mathrm{Cl}\right]_{n}$ in the presence of $\mathrm{AgBF}_{4}$ in THF solution. The variable-temperature (VT) magnetic susceptibility measurements were performed in the 2-300 K temperature range for both complexes. The comparison of the VT magnetic behaviors indicated that a considerably large antiferromagnetic interaction through the axial chlorido-bridge exists for $\left[\mathrm{Ru}_{2}(\mathrm{PhCONH})_{4} \mathrm{Cl}\right]_{n}\left(z J=-2.8 \mathrm{~cm}^{-1}\right)$, but not for $\mathrm{Ru}_{2}(\mathrm{HNOCPh})_{4} \mathrm{BF}_{4} \cdot \mathrm{H}_{2} \mathrm{O}\left(z J=-0.08 \mathrm{~cm}^{-1}\right)$, in addition to the fact that both of the complexes have an $\mathrm{Ru}_{2}{ }^{5+}$ core with a spin sate of $S=3 / 2$, showing a large zero-field splitting $\left(D=61 \mathrm{~cm}^{-1}\right)$ like the other lantern-type $\mathrm{Ru}_{2}{ }^{5+}$ complexes with spin state of $S=3 / 2$ [1-5]. This report describes the electrochemical properties of $\mathrm{Ru}_{2}(\mathrm{HNOCPh})_{4} \mathrm{BF}_{4} \cdot \mathrm{H}_{2} \mathrm{O}$ in dichloromethane containing $\mathrm{Bu}_{4} \mathrm{NPF}_{6}$ as electrolyte, as well as the crystal structure determined for the single crystals obtained by the recrystallization of $\mathrm{Ru}_{2}(\mathrm{HNOCPh})_{4} \mathrm{BF}_{4} \cdot \mathrm{H}_{2} \mathrm{O}$ from acetone.

\section{Results and Discussion}

\subsection{Synthesis and Characterizations}

The axial chloride ligand of $\left[\mathrm{Ru}_{2}(\mathrm{HNOCPh})_{4} \mathrm{Cl}\right]_{n}$ could be removed by chemical reaction with $\mathrm{AgBF}_{4}$ in $\mathrm{THF}$ for $24 \mathrm{~h}$ with stirring at room temperature, giving the tetrafluoroborate salt $\mathrm{Ru}_{2}(\mathrm{HNOCPh})_{4} \mathrm{BF}_{4} \cdot \mathrm{H}_{2} \mathrm{O}$, the chemical formation of which was confirmed by elemental analysis in addition to the fact that ESI-TOF MS and IR spectra showed a main peak corresponding to the cationic species $\left[\mathrm{Ru}_{2}(\mathrm{HNOCPh})_{4}\right]^{+}(683.9904 \mathrm{~m} / z)$ and a predominant absorption appearing around $1100 \mathrm{~cm}^{-1}$ due to $\mathrm{BF}_{4}{ }^{-}$ion [22]. The IR spectra of $\left[\mathrm{Ru}_{2}(\mathrm{HNOCPh})_{4} \mathrm{Cl}\right]_{n}$ and $\mathrm{Ru}_{2}(\mathrm{HNOCPh})_{4} \mathrm{BF}_{4} \cdot \mathrm{H}_{2} \mathrm{O}$ are given in Figure 1; their spectral features are basically the same, other than the band due to the $\mathrm{BF}_{4}{ }^{-}$ion, which indicates that $\mathrm{Ru}_{2}(\mathrm{HNOCPh})_{4} \mathrm{BF}_{4} \cdot \mathrm{H}_{2} \mathrm{O}$ has a $\mathrm{Ru}_{2}{ }^{5+}$ core unit similar to that of $\left[\mathrm{Ru}_{2}(\mathrm{HNOCPh})_{4} \mathrm{Cl}\right]_{n}$. Furthermore, the $\mathrm{BF}_{4}{ }^{-}$ion and water molecule are coordinated to the dinuclear core with a unidentate mode, as shown below for the crystal structure of $\left[\mathrm{Ru}_{2}(\mathrm{HNOCPh})_{4}\left(\mathrm{BF}_{4}\right)\left(\mathrm{H}_{2} \mathrm{O}\right)\right] \cdot 2$ (acetone). Hereafter, $\mathrm{Ru}_{2}(\mathrm{HNOCPh})_{4} \mathrm{BF}_{4} \cdot \mathrm{H}_{2} \mathrm{O}$ is described as $\left[\mathrm{Ru}_{2}(\mathrm{HNOCPh})_{4}\left(\mathrm{BF}_{4}\right)\left(\mathrm{H}_{2} \mathrm{O}\right)\right]$. In the diffuse reflectance spectra (Figure 2), the NIR band assigned as $\delta\left(\mathrm{Ru}_{2}{ }^{5+}\right) \rightarrow \delta^{*}\left(\mathrm{Ru}_{2}{ }^{5+}\right)$ was observed at 988 and $978 \mathrm{~nm}$ 
for $\left[\mathrm{Ru}_{2}(\mathrm{HNOCPh})_{4} \mathrm{Cl}\right]_{n}$ and $\left[\mathrm{Ru}_{2}(\mathrm{HNOCPh})_{4}\left(\mathrm{BF}_{4}\right)\left(\mathrm{H}_{2} \mathrm{O}\right)\right]$, respectively, in addition to the bands assigned as $\pi\left(\mathrm{Ru}-\mathrm{O} / \mathrm{N}, \mathrm{Ru}_{2}{ }^{5+}\right) \rightarrow \delta^{*}\left(\mathrm{Ru}_{2}{ }^{5+}\right)$ at $484 \mathrm{~nm}\left(\right.$ for $\left.\left[\mathrm{Ru}_{2}(\mathrm{HNOCPh})_{4} \mathrm{Cl}\right]_{n}\right)$ and $440 \mathrm{~nm}$ (for $\left.\left[\mathrm{Ru}_{2}(\mathrm{HNOCPh})_{4}\left(\mathrm{BF}_{4}\right)\left(\mathrm{H}_{2} \mathrm{O}\right)\right]\right)$. The band observed at $352 \mathrm{~nm}$ for both complexes could be attributed to the axial ligand $\left(\mathrm{Cl}^{-}\right.$or $\left.\mathrm{BF}_{4}{ }^{-}\right) \rightarrow \sigma^{*}\left(\mathrm{Ru}_{2}{ }^{5+}\right)$ charge transfer $[1,3,11,13,14,17]$. The absorption spectrum was measured for $\left[\mathrm{Ru}_{2}(\mathrm{HNOCPh})_{4}\left(\mathrm{BF}_{4}\right)\left(\mathrm{H}_{2} \mathrm{O}\right)\right]$ in dichloromethane, although $\left[\mathrm{Ru}_{2}(\mathrm{HNOCR})_{4} \mathrm{Cl}\right]_{n}$ was completely insoluble in less-donating solvents such as dichloromethane; hence, strongly donating solvents such as DMSO were used for the physicochemical measurements in the solution $[11,12,14]$. The absorption spectrum (Figure 3$)$ of $\left[\mathrm{Ru}_{2}(\mathrm{HNOCPh})_{4}\left(\mathrm{BF}_{4}\right)\left(\mathrm{H}_{2} \mathrm{O}\right)\right]$ in dichloromethane showed bands at 360, 470 and $965 \mathrm{~nm}$ similar to those in solid $(352,440$ and $978 \mathrm{~nm}$ in the diffuse reflectance spectrum). This suggests that the dinuclear structure $\left[\mathrm{Ru}_{2}(\mathrm{HNOCPh})_{4}\left(\mathrm{BF}_{4}\right)\left(\mathrm{H}_{2} \mathrm{O}\right)\right]$ is maintained in the dichloromethane solution.

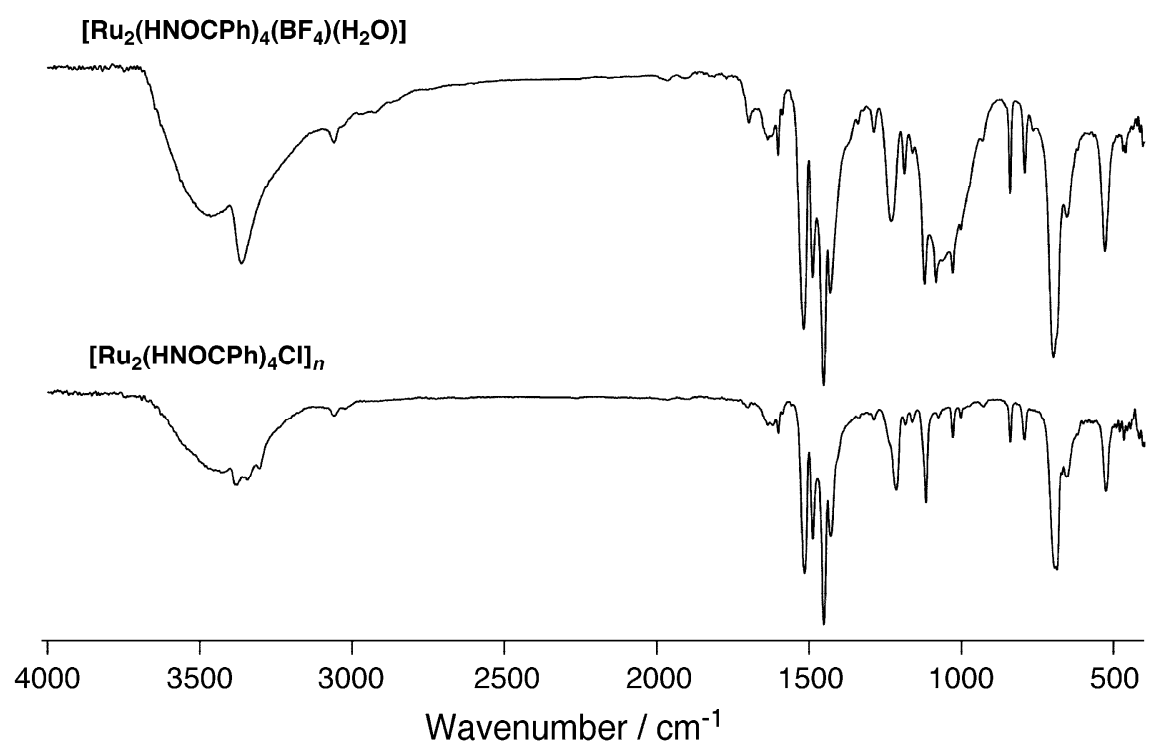

Figure 1. IR spectra of $\left[\mathrm{Ru}_{2}(\mathrm{HNOCPh})_{4}\left(\mathrm{BF}_{4}\right)\left(\mathrm{H}_{2} \mathrm{O}\right)\right]$ and $\left[\mathrm{Ru}_{2}(\mathrm{HNOCPh})_{4} \mathrm{Cl}\right]_{n}$.

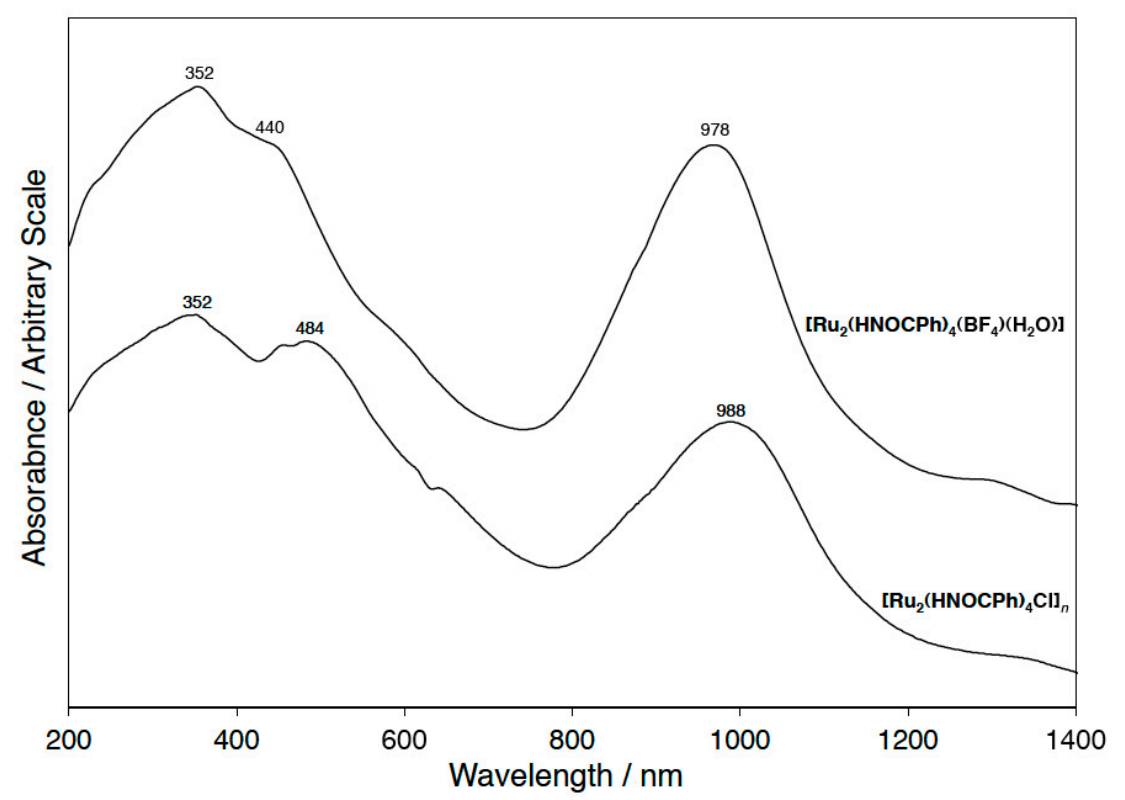

Figure 2. Diffuse reflectance spectra of $\left[\mathrm{Ru}_{2}(\mathrm{HNOCPh})_{4}\left(\mathrm{BF}_{4}\right)\left(\mathrm{H}_{2} \mathrm{O}\right)\right]$ and $\left[\mathrm{Ru}_{2}(\mathrm{HNOCPh})_{4} \mathrm{Cl}\right]_{n}$. 


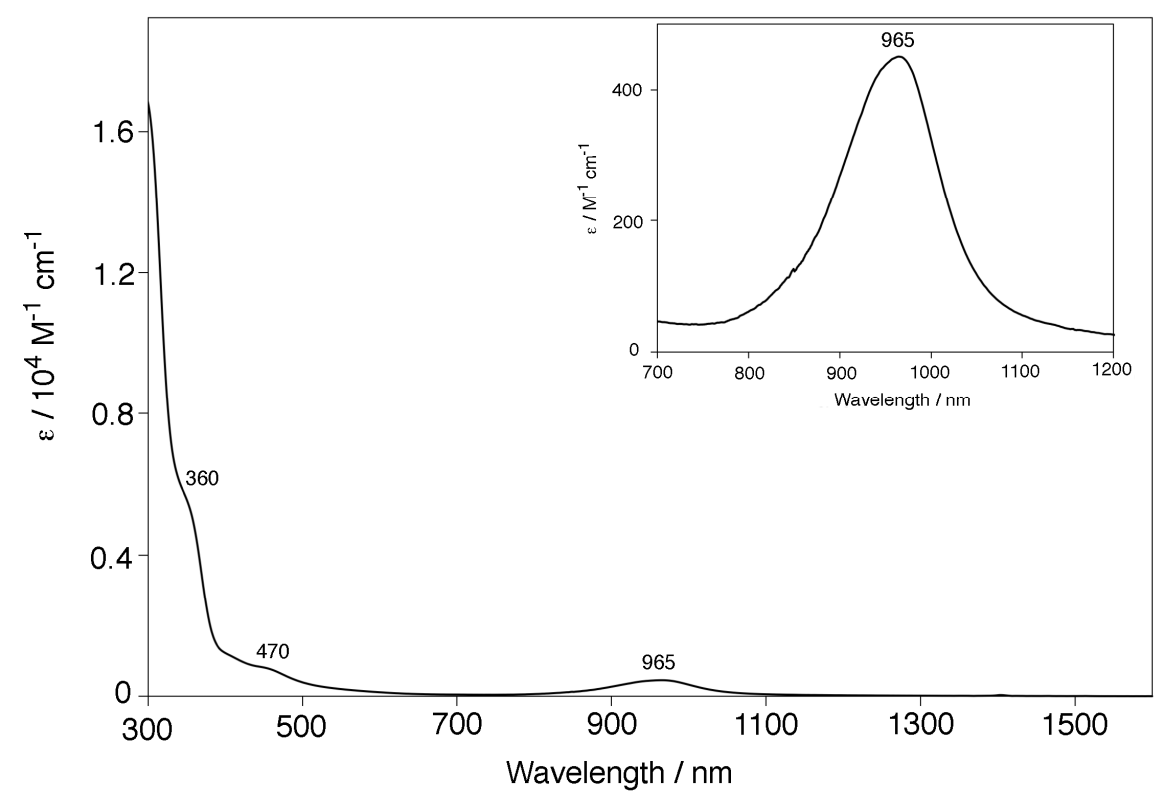

Figure 3. Absorption spectra of $\left[\mathrm{Ru}_{2}(\mathrm{HNOCPh})_{4}\left(\mathrm{BF}_{4}\right)\left(\mathrm{H}_{2} \mathrm{O}\right)\right]$ in $\mathrm{CH}_{2} \mathrm{Cl}_{2}$.

\subsection{Cyclic Voltammogram $(\mathrm{CV})$ of $\left[\mathrm{Ru} u_{2}(\mathrm{HNOCPh})_{4}\left(B F_{4}\right)\left(\mathrm{H}_{2} \mathrm{O}\right)\right]$}

The electrochemical redox behavior of $\left[\mathrm{Ru}_{2}(\mathrm{HNOCPh})_{4}\left(\mathrm{BF}_{4}\right)\left(\mathrm{H}_{2} \mathrm{O}\right)\right]$ was investigated by the $\mathrm{CV}$ technique in dried dichloromethane containing $0.1 \mathrm{M} \mathrm{Bu}_{4} \mathrm{NPF}_{6}$ as electrolyte. The result is shown in Figure 4 . The redox wave at $E_{1 / 2}\left(\left(E_{\mathrm{pa}}+E_{\mathrm{pc}}\right) / 2\right)=1.12 \mathrm{~V}$ (vs. SCE) in the oxidation side was attributed to $\mathrm{Ru}_{2}{ }^{6+} / \mathrm{Ru}_{2}{ }^{5+}$ couple on referring to the $\mathrm{CV}$ results obtained for the $\mathrm{Ru}_{2}{ }^{5+}$ complexes with amidato bridges [11-13,18], while irreversible waves were subsequently shown at ca. -0.5 and ca. $-1.0 \mathrm{~V}$ (vs. SCE), the former being possibly attributable to the $\mathrm{Ru}_{2}{ }^{5+} / \mathrm{Ru}_{2}{ }^{4+}$ process. It has been previously reported that $\left[\mathrm{Ru}_{2}(\mathrm{HNOCPh})_{4} \mathrm{Cl}\right]_{n}$ exhibits a $\mathrm{Ru}_{2}{ }^{6+} / \mathrm{Ru}_{2}{ }^{5+}$ wave at $0.66 \mathrm{~V}$ (vs. SCE) and an irreversible $\mathrm{Ru}_{2}{ }^{5+} / \mathrm{Ru}_{2}{ }^{4+}$ wave at ca. $-0.50 \mathrm{~V}$ (vs. SCE) in DMSO containing $0.1 \mathrm{M} \mathrm{Bu}_{4} \mathrm{NClO}_{4}$ and excess of $\mathrm{Cl}^{-}$, while the $\mathrm{Ru}_{2}{ }^{6+} / \mathrm{Ru}_{2}{ }^{5+}$ wave was not observed in DMSO containing $0.1 \mathrm{M} \mathrm{Bu}_{4} \mathrm{NClO}_{4}$ without addition of $\mathrm{Cl}^{-}$, and redox couples associated with $\mathrm{Ru}_{2}{ }^{5+} / \mathrm{Ru}_{2}{ }^{4+}$ process were subsequently observed at -0.70 and $-1.13 \mathrm{~V}$ (vs. SCE) [13]. The complex redox behaviors reported for $\left[\mathrm{Ru}_{2}(\mathrm{HNOCPh})_{4} \mathrm{Cl}\right]_{n}$ in the DMSO solution may be due to the strong donating nature of DMSO, participating in the axial coordination instead of $\mathrm{Cl}^{-}$. Because the dinuclear structure of $\left[\mathrm{Ru}_{2}(\mathrm{HNOCPh})_{4}\left(\mathrm{BF}_{4}\right)\left(\mathrm{H}_{2} \mathrm{O}\right)\right]$ is maintained in the less-donating dichloromethane solution, the redox behavior is considered to be rather simple and similar to that reported for $\left[\mathrm{Ru}_{2}(\mathrm{HNOCPh})_{4} \mathrm{Cl}\right]_{n}$ in DMSO solution containing an excess of $\mathrm{Cl}^{-}$[13]. The lantern-type dinuclear complex $\left[\mathrm{Ru}_{2}(\mathrm{bam})_{4} \mathrm{Cl}_{2}\right]\left(\right.$ bam ${ }^{-}=$benzamidinate ion (Scheme 2a)) favors the oxidation state of $\mathrm{Ru}_{2}(\mathrm{III}, \mathrm{III})$, mainly due to the strong donating nature of a benzamidinato bridging ligand having an $\mathrm{N}, \mathrm{N}$-donor set compared with the amidato bridging ligand with the $\mathrm{N}, \mathrm{O}$-donor set in $\left[\mathrm{Ru}_{2}\left(\left[\mathrm{Ru}_{2}(\mathrm{HNOCPh})_{4}\left(\mathrm{BF}_{4}\right)\left(\mathrm{H}_{2} \mathrm{O}\right)\right]\right.\right.$, although the difference in the axial ligands should be taken into account. In the case of $\left[\mathrm{Ru}_{2}(\mathrm{bam})_{4} \mathrm{Cl}_{2}\right]$, the $\mathrm{Ru}_{2}{ }^{6+} / \mathrm{Ru}_{2}{ }^{5+}$ couple was observed at $E_{1 / 2}=-0.231 \mathrm{~V}$ (vs. SCE) in chloroform containing $0.1 \mathrm{M} \mathrm{Bu}_{4} \mathrm{NPF}_{6}$ [23]; the redox potential is negatively shifted in potential compared with that of $\left[\mathrm{Ru}_{2}(\mathrm{HNOCPh})_{4}\left(\mathrm{BF}_{4}\right)\left(\mathrm{H}_{2} \mathrm{O}\right)\right]$. The large irreversible wave at ca. $-1.0 \mathrm{~V}$ vs. SCE observed for $\left[\mathrm{Ru}_{2}(\mathrm{HNOCPh})_{4}\left(\mathrm{BF}_{4}\right)\left(\mathrm{H}_{2} \mathrm{O}\right)\right]$ could be related to its decomposition. 


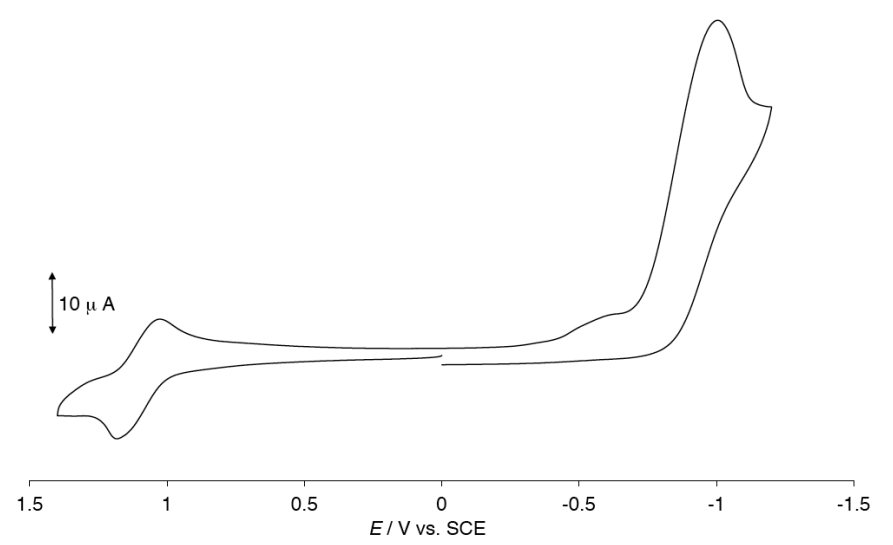

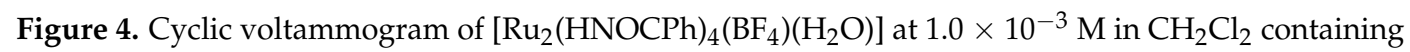
$0.1 \mathrm{M} \mathrm{Bu}_{4} \mathrm{NPF}_{6}$ (glassy carbon working electrode; scan rate $=100 \mathrm{mV} / \mathrm{s}$ ).<smiles>N=C(N)c1ccccc1</smiles>

(a) bam-<smiles>C=NC(=NC)c1ccccc1</smiles>

(b) DMBA-<smiles>[N-]=Nc1ccccn1</smiles>

(c) $\mathrm{ap}^{-}$

Scheme 2. Chemical structures of benzamidinate $\left(\mathrm{bam}^{-}\right), N, N^{\prime}$-dimethylbenzamidinate $\left(\mathrm{DMBA}^{-}\right)$and 2-alinopyridinate $\left(\mathrm{ap}^{-}\right)$ligands.

\subsection{Crystal Structure of $\left[R u_{2}(H N O C P h)_{4}\left(B F_{4}\right)\left(\mathrm{H}_{2} \mathrm{O}\right)\right] \cdot 2$ (acetone)}

Single crystals suitable for $\mathrm{X}$-ray crystal structure analysis were obtained as those of $\left[\mathrm{Ru}_{2}(\mathrm{HNOCPh})_{4}\left(\mathrm{BF}_{4}\right)\left(\mathrm{H}_{2} \mathrm{O}\right)\right] \cdot 2$ (acetone) by the recrystallization of $\left[\mathrm{Ru}_{2}(\mathrm{HNOCPh})_{4}\left(\mathrm{BF}_{4}\right)\left(\mathrm{H}_{2} \mathrm{O}\right)\right]$ from acetone. The molecular structure and its selected bond distances and angles are given in Figure 5 and Table S1, respectively. Four amidato ligands bridge two ruthenium ions with a cis-(2:2) arrangement of the ligands around $\mathrm{Ru}_{2}{ }^{\mathrm{II}, \mathrm{III}}$ core, giving a lantern-like structure. The Ru1-Ru2 distance is 2.2793(4) $\AA$, which is shorter than the corresponding distances (2.295(2) and 2.290(2) $\AA$ ) of $\left[\mathrm{Ru}_{2}(\mathrm{HNOCPh})_{4} \mathrm{Cl}\right]_{n}$, in which chloride ions axially coordinate to ruthenium ions with $\mathrm{Ru}-\mathrm{Cl}_{\mathrm{ax}}$ distances of 2.572(3) and 2.612(3) $\AA$ to link the $\mathrm{Ru}_{2}{ }^{5+}$ units, resulting in a zigzag chain structure with a Ru-Clax $-\mathrm{Ru}$ bond angle of $116.2(1)^{\circ}$ [15]. In [ $\left.\mathrm{Ru}_{2}(\mathrm{HNOCPh})_{4}\left(\mathrm{BF}_{4}\right)\left(\mathrm{H}_{2} \mathrm{O}\right)\right] \cdot 2$ (acetone), both axial positions of the $\mathrm{Ru}_{2}{ }^{5+}$ unit are occupied with fluorine $\left(\mathrm{BF}_{4}{ }^{-}\right)$and oxygen $\left(\mathrm{H}_{2} \mathrm{O}\right)$ atoms with Ru1-F1 and Ru2-O5 distances of 2.3265(19) and 2.280(2) $\AA$, respectively. To our knowledge, only two complexes $\left[\mathrm{Ru}_{2}{ }^{\mathrm{III}, \mathrm{III}}(\mathrm{DMBA})_{4}\left(\mathrm{BF}_{4}\right)_{2}\right]\left(\mathrm{DMBA}^{-}=N, N^{\prime}\right.$-dimethylbenzamidinate ion (Scheme $2 \mathrm{~b})$ ) and $\left[\mathrm{Ru}_{2}{ }^{\mathrm{II}, \mathrm{III}}(\mathrm{ap})\left(\mathrm{BF}_{4}\right)\right] \cdot 2 \mathrm{THF}\left(\mathrm{ap}^{-}=2\right.$-anilinopyridinate ion (Scheme $\left.2 \mathrm{c}\right)$ ) have been confirmed by the X-ray crystal structure analysis for the axial coordination of $\mathrm{BF}_{4}{ }^{-}$to the lantern-type diruthenium complex [24,25]. The Ru- $\mathrm{F}_{\mathrm{ax}}$ bond distances are 2.366(3) and 2.389(3) $\AA$ for [ $\left[\mathrm{Ru}_{2}{ }^{\mathrm{III}, \mathrm{III}}(\mathrm{DMBA})_{4}\left(\mathrm{BF}_{4}\right)_{2}\right]$ [24] and 2.296(2) $\AA$ for $\left[\mathrm{Ru}_{2}{ }^{\mathrm{II}, \mathrm{III}}(\mathrm{ap})\left(\mathrm{BF}_{4}\right)\right] \cdot 2 \mathrm{THF}$ [25]; the bond lengths are similar to that $(2.3265(19) \AA)$ of $\left[\mathrm{Ru}_{2}{ }^{\mathrm{II}}, \mathrm{III}(\mathrm{HNOCPh})_{4}\left(\mathrm{BF}_{4}\right)\left(\mathrm{H}_{2} \mathrm{O}\right)\right] \cdot 2$ (acetone). Acetone molecules exist as the crystal solvent in the crystal. One of the acetone molecules participates in the hydrogen-bonding network within the crystal, as shown in Figure S1. Similar hydrogen-bonding networks have been reported for $\left[\mathrm{Ru}_{2}(\mathrm{HNOCMe})_{4}\left(\mathrm{H}_{2} \mathrm{O}\right)_{2}\right] \mathrm{ClO}_{4}$, $\left[\mathrm{Ru}_{2}(\mathrm{HNOCMe})_{4}\left(\mathrm{H}_{2} \mathrm{O}\right)_{2}\right] \mathrm{NO}_{3}$ and $\left[\mathrm{Ru}_{2}(\mathrm{HNOCMe})_{4}\left(\mathrm{H}_{2} \mathrm{O}\right)_{2}\right]\left(\mathrm{BPh}_{4}\right) \cdot \mathrm{H}_{2} \mathrm{O}$ [26-28]. The acetone molecules in the crystal of $\left[\mathrm{Ru}_{2}(\mathrm{HNOCPh})_{4}\left(\mathrm{BF}_{4}\right)\left(\mathrm{H}_{2} \mathrm{O}\right)\right] \cdot 2$ (acetone) could be easily removed over $\mathrm{P}_{2} \mathrm{O}_{5}$ in a desiccator at ambient temperature and pressure (See Section 3.2). 


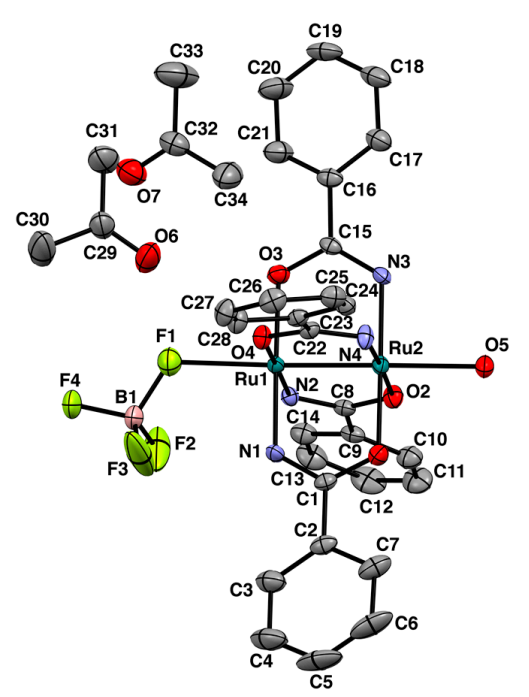

Figure 5. ORTEP drawing of the structure of $\left[\mathrm{Ru}_{2}(\mathrm{HNOCPh})_{4}\left(\mathrm{BF}_{4}\right)\left(\mathrm{H}_{2} \mathrm{O}\right)\right] \cdot 2$ (acetone), showing a $50 \%$ probability of thermal ellipsoids and atom labeling scheme. Hydrogen atoms are omitted for clarity.

\subsection{Magnetic Properties}

In Figures 6 and 7, variable-temperature (VT) magnetic susceptibilities and moments are shown in the measured 2-300 K temperature range for $\left[\mathrm{Ru}_{2}(\mathrm{HNOCPh})_{4} \mathrm{Cl}\right]_{n}$ and $\left[\mathrm{Ru}_{2}(\mathrm{HNOCPh})_{4}\left(\mathrm{BF}_{4}\right)\left(\mathrm{H}_{2} \mathrm{O}\right)\right]$, respectively. The magnetic moment (per $\mathrm{Ru}_{2}{ }^{5+}$ unit) of $\left[\mathrm{Ru}_{2}(\mathrm{HNOCPh})_{4} \mathrm{Cl}\right]_{n}$ is $4.15 \mu_{\mathrm{B}}$ at $300 \mathrm{~K}$, which indicates the existence of three unpaired electrons per the $\mathrm{Ru}_{2}{ }^{5+}$ unit with an $S=3 / 2$ state. Like the other halogenido $(\mathrm{X})$-linked $\mathrm{Ru}_{2}{ }^{5+}$ polymer complexes, the magnetic moment decreases with decrease in the temperature, due to zero-field splitting $(D)$, followed by a further steep decrease in the moment when the temperature is approaching $2 \mathrm{~K}$, due to the antiferromagnetic interaction through the axial chloride ion $[5,17,19,20]$. The magnetic moment of $\left[\mathrm{Ru}_{2}(\mathrm{HNOCPh})_{4}\left(\mathrm{BF}_{4}\right)\left(\mathrm{H}_{2} \mathrm{O}\right)\right]$ is $3.84 \mu_{\mathrm{B}}$ at $300 \mathrm{~K}$, which is also indicative of the spin state of $S=3 / 2$ for this complex, and decreases with decrease in temperature due to zero-field splitting, without the steep decrease in the moment even when the temperature is close to $2 \mathrm{~K}$.

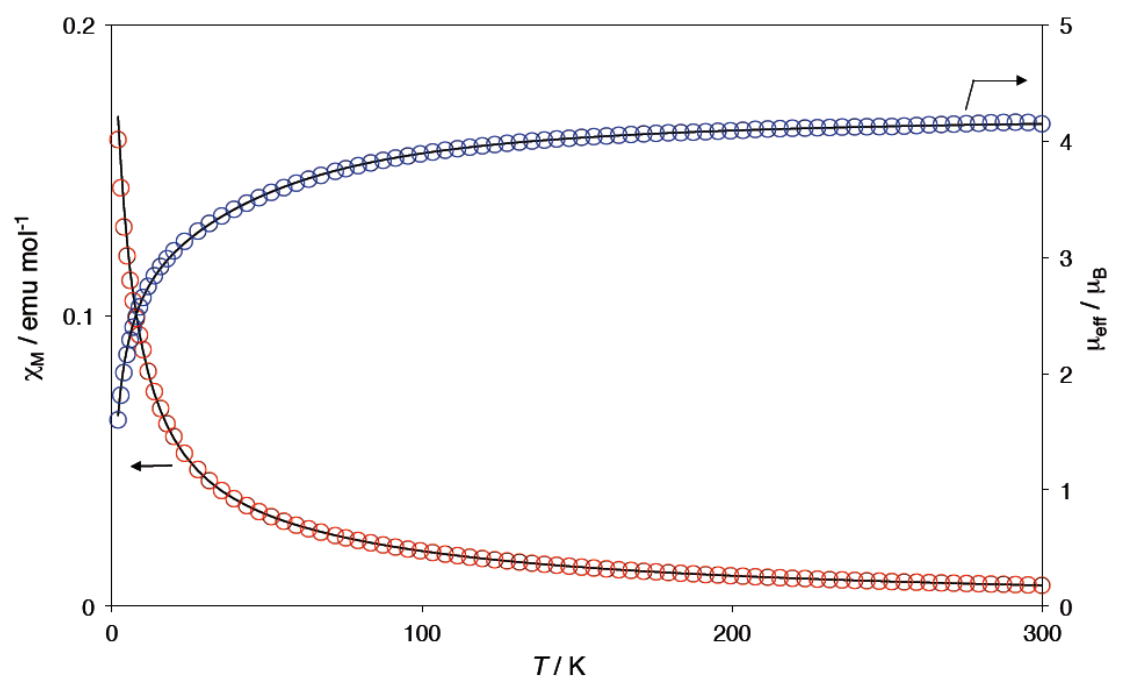

Figure 6. Variable temperature of magnetic susceptibility $\chi_{M}$ (red circles) and moment $\mu_{\text {eff }}$ (blue circles) for $\left[\mathrm{Ru}_{2}(\mathrm{HNOCPh})_{4} \mathrm{Cl}\right]_{n}$. The solid black lines were calculated and drawn with the parameter values described in the text. 


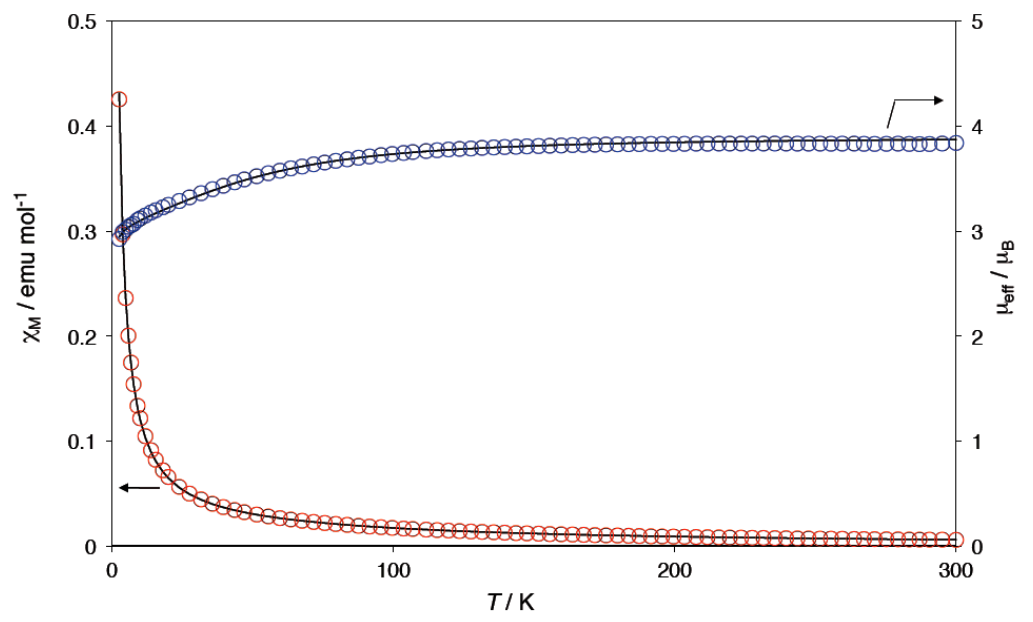

Figure 7. Variable temperature of magnetic susceptibility $\chi_{M}$ (red circles) and moment $\mu_{\text {eff }}$ (blue circles) for $\left[\mathrm{Ru}_{2}(\mathrm{HNOCPh})_{4}\left(\mathrm{BF}_{4}\right)\left(\mathrm{H}_{2} \mathrm{O}\right)\right]$. The solid black lines were calculated and drawn with the parameter values described in the text.

VT magnetic behaviors are conventionally simulated using the Equations (1)-(4), described below, for the $S=3 / 2$ system with a zero-field splitting of $\mathrm{Ru}_{2}{ }^{5+}$ species, the inter-dinuclear-unit interaction being taken into account by means of a mean-field approximation [3,5,29-31]:

$$
\chi^{\prime}=\chi /\left\{1-\left(2 z J / N g^{2} \mu_{\mathrm{B}}^{2}\right) \chi\right\}
$$

where $z J$ is the exchange energy multiplied by the number $(z)$ of interacting neighbors, and $\chi$ is the magnetic susceptibility.

$$
x=\left(x_{/ /}+2 x_{\perp}\right) / 3
$$

where $\chi_{/ /}$and $\chi_{\perp}$ are magnetic susceptibility terms defined as follows:

$$
\begin{gathered}
\chi_{/ /}=\left(N g^{2} \mu_{\mathrm{B}}^{2} / k T\right)\{1+9 \exp (-2 D / k T)\} / 4\{1+\exp (-2 D / k T)\} \\
\chi_{\perp}=\left(N g^{2} \mu_{\mathrm{B}}^{2} / \mathrm{kT}\right)[4+(3 k T / D)\{1-\exp (-2 D / k T)\}] / 4\{1+\exp (-2 D / k T)\}
\end{gathered}
$$

The simulation results gave parameter values: $g=2.19, D=61 \mathrm{~cm}^{-1}, z J=-2.8 \mathrm{~cm}^{-1}$ for $\left[\mathrm{Ru}_{2}(\mathrm{HNOCPh})_{4} \mathrm{Cl}\right]_{n}$ and $g=2.01, D=61 \mathrm{~cm}^{-1}, z J=-0.08 \mathrm{~cm}^{-1}$ for $\left[\mathrm{Ru}_{2}(\mathrm{HNOCPh})_{4}\left(\mathrm{BF}_{4}\right)\left(\mathrm{H}_{2} \mathrm{O}\right)\right]$. There is a considerable difference in $z J$ value between $\left[\mathrm{Ru}_{2}(\mathrm{HNOCPh})_{4} \mathrm{Cl}\right]_{n}$ and $\left[\mathrm{Ru}_{2}(\mathrm{HNOCPh})_{4}\left(\mathrm{BF}_{4}\right)\left(\mathrm{H}_{2} \mathrm{O}\right)\right]$. The appreciable magnetic interaction $\left(z J=-2.8 \mathrm{~cm}^{-1}\right)$ is operative through the axial chlorido linker for $\left[\mathrm{Ru}_{2}(\mathrm{HNOCPh})_{4} \mathrm{Cl}\right]_{n}$, although through-space interaction $\left(z J=-0.08 \mathrm{~cm}^{-1}\right)$ only occurs in $\left[\mathrm{Ru}_{2}(\mathrm{HNOCPh})_{4}\left(\mathrm{BF}_{4}\right)\left(\mathrm{H}_{2} \mathrm{O}\right)\right]$. A similar discussion has been presented by Barral et al. for $\left[\mathrm{Ru}_{2}(\mathrm{HNOCR})_{4} \mathrm{Cl}\right]_{n}\left(z J=-0.3--2.9 \mathrm{~cm}^{-1}\right)$ and $\left[\mathrm{Ru}_{2}(\mathrm{HNOCR})_{4}(\mathrm{THF})_{2}\right] \mathrm{Y}$ $\left(-0.1--2.2 \mathrm{~cm}^{-1}\right)$, where $\mathrm{R}=\mathrm{C}_{6} \mathrm{H}_{3}-3,5-(\mathrm{OMe})_{2}, \mathrm{C}_{6} \mathrm{H}_{4}-p-\mathrm{OMe}, \mathrm{C}_{6} \mathrm{H}_{4}-p-\mathrm{CMe}_{3}, \mathrm{C}_{4} \mathrm{H}_{3} \mathrm{~S}, \mathrm{C}_{6} \mathrm{H}_{11}, \mathrm{CMe}_{3}$ and $\mathrm{Y}=\mathrm{BF}_{4}{ }^{-}, \mathrm{SbF}_{6}{ }^{-}$[17]. Later, using the crystal structural data, an empirical linear relationship was proposed between through-axial halogenido $(X)$ magnetic interaction $z J$ and the structural parameter $\mathrm{Ru}-\mathrm{X} / \mathrm{Ru}-\mathrm{X}-\mathrm{Ru}$ for lantern-type $\mathrm{Ru}_{2}{ }^{5+}$ complexes with amidato or carboxylato bridges [20]. According to the relationship, $z J$ is estimated as ca. $-3.0 \mathrm{~cm}^{-1}$ using the crystal data of $\left[\mathrm{Ru}_{2}(\mathrm{PhCONH})_{4} \mathrm{Cl}\right]_{n}$ reported by Chakravarty and Cotton [15], which is almost consistent with the present magnetic result of $z J=-2.8 \mathrm{~cm}^{-1}$ for the complex.

\subsection{DFT Calculations}

The present complex $\left[\mathrm{Ru}_{2}(\mathrm{HNOCPh})_{4}\left(\mathrm{BF}_{4}\right)\left(\mathrm{H}_{2} \mathrm{O}\right)\right]$ obtained from $\left[\mathrm{Ru}_{2}(\mathrm{HNOCPh})_{4} \mathrm{Cl}\right]_{n}$ by the removal of axial chlorido linker does not have empty axial positions, as in the case of $\left[\mathrm{Ru}_{2}(\mathrm{DArF})_{4}\right] \mathrm{BF}_{4}$. 
Hence, in order to clarify the favorable spin states, electronic structures and spin density distributions of $\left[\mathrm{Ru}_{2}(\mathrm{HNOCPh})_{4}\left(\mathrm{BF}_{4}\right)\left(\mathrm{H}_{2} \mathrm{O}\right)\right]$ and $\left[\mathrm{Ru}_{2}(\mathrm{HNOCPh})_{4} \mathrm{Cl}_{2}\right]^{-}$, as well as $\left[\mathrm{Ru}_{2}(\mathrm{HNOCPh})_{4}\right]^{+}$, which is the theoretically modeled complex with empty axial sites, unrestricted density functional theory (uDFT) calculations were performed.

Our zero-point energy (ZPE) calculations clearly supported the experimentally observed spin state of $\left[\mathrm{Ru}_{2}(\mathrm{HNOCPh})_{4}\left(\mathrm{BF}_{4}\right)\left(\mathrm{H}_{2} \mathrm{O}\right)\right]$; the $\mathrm{ZPE}$ with the $S=3 / 2$ spin state is $7.68 \mathrm{Kcal} / \mathrm{mol} \mathrm{more} \mathrm{stable}$ than that with the $S=1 / 2$ spin state. The ZPEs of $\left[\mathrm{Ru}_{2}(\mathrm{HNOCPh})_{4} \mathrm{Cl}_{2}\right]^{-}$and $\left[\mathrm{Ru}_{2}(\mathrm{HNOCPh})_{4}\right]^{+}$with the $S=3 / 2$ spin state were also 3.16 and $3.76 \mathrm{Kcal} / \mathrm{mol}$ more stable, respectively, than those with the $S=1 / 2$ spin state, indicating that the axial ligation of the diruthenium(II,III) complexes with amidato-bridges do not affect the spin state of $S=3 / 2$. In the optimized geometry for the $S=3 / 2$ spin state, the electronic configuration of $\left[\mathrm{Ru}_{2}(\mathrm{HNOCPh})_{4}\left(\mathrm{BF}_{4}\right)\left(\mathrm{H}_{2} \mathrm{O}\right)\right]$ is $\pi^{4} \sigma^{2} \delta^{2} \pi^{* 2} \delta^{* 1}$, as depicted in Figure 8. Three singly occupied molecular orbitals (SOMOs), which are observed at MO-169 $\alpha \sim 167 \alpha$, are assigned as $\delta^{*}\left(\mathrm{Ru}_{2}\right), \pi^{*}\left(\mathrm{Ru}_{2}\right)$, and $\pi^{*}\left(\mathrm{Ru}_{2}\right)$ orbitals, respectively. That is, the MO energies of anti-bonding interactions between $\mathrm{Ru}_{2}$ ions of $\left[\mathrm{Ru}_{2}(\mathrm{HNOCPh})_{4}\left(\mathrm{BF}_{4}\right)\left(\mathrm{H}_{2} \mathrm{O}\right)\right]$ are relatively unstable compared to those of bonding orbital interactions between $\mathrm{Ru}_{2}$ ions similarly to those of typical diruthenium(II,III) tetracarboxylate complexes [1,3]. The most unstable bonding orbital interactions between $\mathrm{Ru}_{2}$ ions are the $\delta\left(\mathrm{Ru}_{2}\right)$ orbitals, which are observed at MO-166 $\alpha$ and $166 \beta$. The $\sigma\left(\mathrm{Ru}_{2}\right)$ orbitals, which interact with the orbitals of atoms located at primary coordination spheres, are located at MO-157 $\alpha$ and $153 \beta$. The degenerate $\pi\left(\mathrm{Ru}_{2}\right)$ orbitals are found at MO-145 $\alpha, 146 \alpha, 163 \beta$ and $164 \beta$, in which $\pi\left(\mathrm{Ru}_{2}\right)$ orbitals are considerably overlapped with the $p(\mathrm{~N})$ and $p(\mathrm{O})$ orbitals of amidato moieties. On the other hand, the lowest unoccupied MOs (LUMOs) of $\alpha$ and $\beta$ orbitals are $\sigma^{*}\left(\mathrm{Ru}_{2}\right)$ and $\delta^{*}\left(\mathrm{Ru}_{2}\right)$ orbitals, respectively. The SOMO-LUMO and highest-occupied MO (HOMO)-LUMO gaps at $\alpha$ and $\beta$ orbitals are estimated as 4.09 and $2.57 \mathrm{eV}$, respectively.

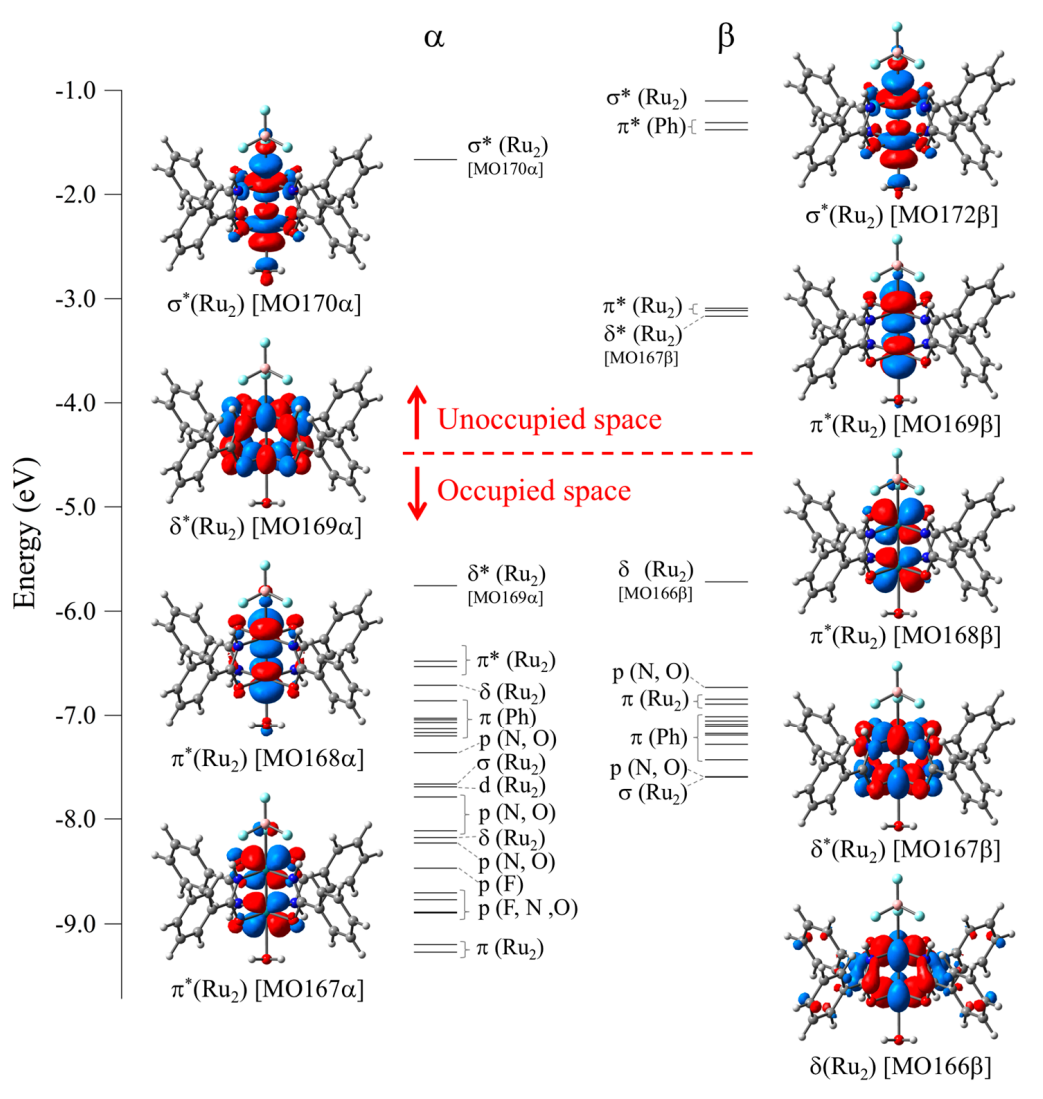

Figure 8. Molecular orbital diagram and selected $\mathrm{MOs}$ of $\left[\mathrm{Ru}_{2}(\mathrm{HNOCPh})_{4}\left(\mathrm{BF}_{4}\right)\left(\mathrm{H}_{2} \mathrm{O}\right)\right]$. 
The DFT calculation treatments are essentially the same between the previous work on $\left[\mathrm{Ru}_{2}(\mathrm{DArF})_{4}\right]^{+}[10]$ and the present one on $\left[\mathrm{Ru}_{2}(\mathrm{HNOCPh})_{4}\right]^{+}$. When taking into consideration the fact that theoretical calculation results on diruthenium(II,III) tetracarboxylate complexes have been in accordance with the $S=3 / 2$ ground state $[1-3,32]$, we can also say that $\left[\mathrm{Ru}_{2}(\mathrm{DArF})_{4}\right] \mathrm{BF}_{4}$ is a unique complex with an $S=1 / 2$ ground state due to the $\pi^{* 3}$ electronic configuration, where the $\delta^{*}$ orbital is energetically higher than the $\pi^{*}$ orbitals in the case of no anti-bonding $\pi$-type interactions with axial ligands having a $\pi$ character, such as $\mathrm{Cl}^{-}$ions [10].

\section{Materials and Methods}

\subsection{General Aspects}

All reagents and solvents were used as received. The precursor complex $\left[\mathrm{Ru}_{2}\left(\mathrm{O}_{2} \mathrm{CCMe}\right)_{4} \mathrm{Cl}\right]_{n}$ was prepared according to a published procedure [33].

Elemental analyses for carbon, hydrogen, and nitrogen were performed using a Yanako CHN Corder MT-6. Infrared spectra (KBr pellets) were measured with a JASCO FT/IR-4600. Absorption spectra and diffuse spectra were obtained using JASCO V-670 and Shimadzu UV-3100 spectrometers, respectively. ESI-TOF mass spectra were taken on a Bruker microTOF. The variable temperature magnetic susceptibilities were measured over the temperature range of $2-300 \mathrm{~K}$ at the constant field of $0.5 \mathrm{~T}$ with a Quantum Design MPMS3 and MPMS XL-5 for $\left[\mathrm{Ru}_{2}(\mathrm{HNOCPh})_{4} \mathrm{Cl}\right]_{n}$ and $\left[\mathrm{Ru}_{2}(\mathrm{HNOCPh})_{4}\left(\mathrm{BF}_{4}\right)\left(\mathrm{H}_{2} \mathrm{O}\right)\right]$, respectively. The measured data were corrected for diamagnetic contributions [34]. Cyclic voltammograms (CVs) were measured in dichloromethane containing tetra- $n$-butylammonium hexafluoroborate $\mathrm{Bu}_{4} \mathrm{NPF}_{6}$ on a BAS ALS-DY2325 electrochemical analyzer. A glassy carbon disk (1.5 mm radius), platinum wire, and saturated calomel electrodes were used as working, counter, and reference electrodes, respectively.

\subsection{Synthesis of Complexes}

\subsubsection{Synthesis of $\left[\mathrm{Ru}_{2}(\mathrm{HNOCPh})_{4} \mathrm{Cl}\right]_{\mathrm{n}}$}

This complex was synthesized using a modified method described in the literature [13]. A $5.0 \mathrm{~g}$ ( $42 \mathrm{mmol}$ ) of $\mathrm{PhCONH}_{2}$ was combined with $0.50 \mathrm{~g}(1.0 \mathrm{mmol})$ of $\mathrm{Ru}_{2}\left(\mathrm{O}_{2} \mathrm{CCH}_{3}\right)_{4} \mathrm{Cl}$ under nitrogen. The mixture was heated to $150{ }^{\circ} \mathrm{C}$ and stirred for $72 \mathrm{~h}$. Excess of the ligand was then removed by sublimation under the reduced pressure, followed by washing thoroughly with acetone and being dried by heating for $3 \mathrm{~h}$ under vacuum to give a brown powder. The yield was $0.68 \mathrm{~g}(96 \%$ based on $\left.\mathrm{Ru}_{2}\left(\mathrm{O}_{2} \mathrm{CCH}_{3}\right)_{4} \mathrm{Cl}\right)$. Anal. Calcd for $\mathrm{Ru}_{2}(\mathrm{HNOCPh})_{4} \mathrm{Cl}: \mathrm{C}, 46.83, \mathrm{H}, 3.37, \mathrm{~N}, 7.80$. Found: $\mathrm{C}, 46.65, \mathrm{H}$, 3.37, N, 7.87\%. IR data (KBr disk, cm $\left.{ }^{-1}\right) 3346 \mathrm{~m}, 3312 \mathrm{~m}, 3065 \mathrm{w}, 1518 \mathrm{~s}, 1489 \mathrm{~s}, 1452 \mathrm{vs}, 1432 \mathrm{~s}, 1217 \mathrm{~s}$, $1118 \mathrm{~s}, 1029 \mathrm{~m}, 841 \mathrm{~m}, 794 \mathrm{~m}, 687 \mathrm{vs}, 657 \mathrm{~s}, 527 \mathrm{~s}$.

\subsubsection{Synthesis of $\left[\mathrm{Ru}_{2}(\mathrm{HNOCPh})_{4}\left(\mathrm{BF}_{4}\right)\left(\mathrm{H}_{2} \mathrm{O}\right)\right]$}

A $50.3 \mathrm{mg}(0.070 \mathrm{mmol})$ of $\mathrm{Ru}_{2}(\mathrm{HNOCPh})_{4} \mathrm{Cl}$ was reacted with $15.0 \mathrm{mg}(0.077 \mathrm{mmol})$ of $\mathrm{AgBF}_{4}$ in THF $(50 \mathrm{~mL})$ with stirring at room temperature for $24 \mathrm{~h}$ in the dark. The white precipitate of $\mathrm{AgCl}$ was removed by filtration over celite. The filtrate was employed for evaporation to remove the solvent. The resultant brown powder was dissolved in chloroform and employed for filtration over celite to further remove $\mathrm{AgCl}$ and unreacted $\mathrm{AgBF}_{4}$. The filtrate was again employed for evaporation to remove the solvent. The formed powder was dissolved in acetone and filtered. The precipitate formed by concentration of the filtrated solution was collected by suction filtration, washed with diethylether and dried over $\mathrm{P}_{2} \mathrm{O}_{5}$ in desiccator for $20 \mathrm{~h}$ to give a yellowish-brown powder. The yield was $31.5 \mathrm{mg}$ (57.1\% based on $\left.\mathrm{Ru}_{2}\left(\mathrm{O}_{2} \mathrm{CMe}\right)_{4} \mathrm{Cl}\right)$. Anal. Calcd for $\left[\mathrm{Ru}_{2}(\mathrm{HNOCPh})_{4}\left(\mathrm{BF}_{4}\right)\left(\mathrm{H}_{2} \mathrm{O}\right)\right]: \mathrm{C}, 42.71, \mathrm{H}, 3.33, \mathrm{~N}$, 7.11. Found: $\mathrm{C}, 42.73, \mathrm{H}, 3.45, \mathrm{~N}, 7.44 \%$. IR data $\left(\mathrm{KBr}\right.$ disk, $\left.\mathrm{cm}^{-1}\right) 3354 \mathrm{~m}, 3050 \mathrm{w}, 1690 \mathrm{~m}, 1616 \mathrm{~m}$, $1600 \mathrm{~m}, 1514 \mathrm{~s}, 1464 \mathrm{~s}, 1450 \mathrm{vs}, 1427 \mathrm{~s}, 1221 \mathrm{~s}, 1118 \mathrm{~s}, 1080 \mathrm{~m}, 1025 \mathrm{~s}, 838 \mathrm{~s}, 790 \mathrm{~m}, 691 \mathrm{vs}, 646 \mathrm{~s}, 522 \mathrm{~s}$, 457 w. HR-ES(ESI-TOF): Found $683.9904 \mathrm{~m} / z$. (calcd for [M] ${ }^{+}$683.9895). 


\subsection{Crystal Structure Determination}

The single crystals of $\left[\mathrm{Ru}_{2}(\mathrm{HNOCPh})_{4}\left(\mathrm{BF}_{4}\right)\left(\mathrm{H}_{2} \mathrm{O}\right)\right] \cdot 2$ (acetone) suitable for X-ray crystal structure analysis were obtained by the recrystallization of $\left[\mathrm{Ru}_{2}(\mathrm{HNOCPh})_{4}\left(\mathrm{BF}_{4}\right)\left(\mathrm{H}_{2} \mathrm{O}\right)\right]$ from acetone. $\mathrm{X}$-ray crystallographic data (Table 1) was collected for a single crystal at 123(2) K on a RIGAKU Saturn 70 CCD system equipped with Mo rotating-anode X-ray generator with monochromated Mo K $\alpha$ radiation $(\lambda=0.71075 \AA$ ). Diffraction data were processed using CrystalClear-SM (RIGAKU). The structure was solved by direct methods (SIR-2011) and refined using the full-matrix least-squares technique $\left(\mathrm{F}^{2}\right)$ with SHELXL-2014 as part of the CrystalStructure 4.2.5 software. Non-hydrogen atoms were refined with anisotropic displacement parameters, and all hydrogen atoms were located at calculated positions and refined with a riding model.

Table 1. Crystallographic data and structure refinement of $\left[\mathrm{Ru}_{2}(\mathrm{HNOCPh})_{4}\left(\mathrm{BF}_{4}\right)\left(\mathrm{H}_{2} \mathrm{O}\right)\right] \cdot 2($ acetone $)$.

\begin{tabular}{|c|c|}
\hline & Parameter Values a \\
\hline Empirical formula & $\mathrm{C}_{34} \mathrm{H}_{38} \mathrm{BF}_{4} \mathrm{~N}_{4} \mathrm{O}_{7} \mathrm{Ru}_{2}$ \\
\hline Formula mass & 903.63 \\
\hline Temperature & $123(2) \mathrm{K}$ \\
\hline Crystal system & Monoclinic \\
\hline Space group & $P 2_{1} / n$ \\
\hline a & $14.412(2) \AA$ \\
\hline $\mathrm{b}$ & $15.669(3) \AA$ \\
\hline c & $16.388(3) \AA$ \\
\hline$\alpha$ & $90^{\circ}$ \\
\hline$\beta$ & $93.743(2)^{\circ}$ \\
\hline$\gamma$ & $90^{\circ}$ \\
\hline Unit-cell volume, $\mathrm{V}$ & $3692.7(10) \AA^{3}$ \\
\hline Formula per unit cell, $\mathrm{Z}$ & 4 \\
\hline Density, $D_{\text {calcd }}$ & $1.625 \mathrm{~g} \mathrm{~cm}^{-3}$ \\
\hline Crystal size & $0.200 \times 0.170 \times 0.050 \mathrm{~mm}$ \\
\hline Absorption coefficient, $\mu$ & $0.890 \mathrm{~mm}^{-1}$ \\
\hline$\theta$ range for data collection & $2.833-27.499^{\circ}$ \\
\hline Reflections collected/unique & $8333 / 7421$ \\
\hline $\mathrm{R}$ indices $[\mathrm{I}>2 \sigma(I)]^{\mathrm{b}}$ & $R_{1}=0.0361, w R_{2}=0.0866$ \\
\hline Goodness-of-fit on $\mathrm{F}^{2}$ & 1.045 \\
\hline
\end{tabular}

${ }^{\mathrm{a}}$ Standard deviations in parentheses; ${ }^{\mathrm{b}} R_{1}=\Sigma|| F_{\mathrm{o}}|-| F_{\mathrm{c}}|| / \Sigma\left|F_{\mathrm{o}}\right| ; w R_{2}=\left[\Sigma w\left(F_{\mathrm{o}}{ }^{2}-F_{\mathrm{c}}{ }^{2}\right)^{2} / \Sigma\left(F_{\mathrm{o}}{ }^{2}\right)^{2}\right]^{1 / 2}$.

CCDC-1835304 contains the supplementary crystallographic data for $\left[\mathrm{Ru}_{2}(\mathrm{HNOCPh})_{4}\left(\mathrm{BF}_{4}\right)\left(\mathrm{H}_{2} \mathrm{O}\right)\right] \cdot 2$ (acetone). These data can be obtained free of charge from the Cambridge Crystallographic Data Centre via www.ccdc.cam.ac.uk/data_request/cif.

\subsection{Computational Details}

All density functional theory (DFT) calculations applied in this study were performed with broken symmetry (BS) uB3LYP functional with LANL08f for Ru atom and 6-31G ${ }^{* *}$ for other atoms. The molecular geometries of $\left[\mathrm{Ru}_{2}(\mathrm{HNOCPh})_{4}\left(\mathrm{BF}_{4}\right)\left(\mathrm{H}_{2} \mathrm{O}\right)\right],\left[\mathrm{Ru}_{2}(\mathrm{PhCONH})_{4} \mathrm{Cl}_{2}\right]^{-}$, and $\left[\mathrm{Ru}_{2}(\mathrm{HNOCPh})_{4}\right]^{+}$were fully optimized in the gas phase, and then the obtained optimized geometries were checked by frequency analysis. The relative energies of their diruthenium complexes with $S=3 / 2$ and $1 / 2$ states were compared with zero-point energies (ZPEs). The molecular orbitals of $\left[\mathrm{Ru}_{2}(\mathrm{HNOCPh})_{4}\left(\mathrm{BF}_{4}\right)\left(\mathrm{H}_{2} \mathrm{O}\right)\right]$ were drawn by a GaussView program.

\section{Conclusions}

A lantern-type diruthenium(II,III) complex $\left[\mathrm{Ru}_{2}(\mathrm{HNOCPh})_{4}\left(\mathrm{BF}_{4}\right)\left(\mathrm{H}_{2} \mathrm{O}\right)\right]$ was prepared from $\left[\mathrm{Ru}_{2}(\mathrm{HNOCPh})_{4} \mathrm{Cl}\right]_{n}$ by removal of the axial chlorido-bridge using $\mathrm{AgBF}_{4}$ in THF. The dinuclear 
structure axially coordinated by $\mathrm{BF}_{4}{ }^{-}$and $\mathrm{H}_{2} \mathrm{O}$ was determined for the former complex by $\mathrm{X}$-ray crystal structure analysis. The temperature dependent magnetic susceptibility and moment data showed that both of the complexes $\left[\mathrm{Ru}_{2}(\mathrm{HNOCPh})_{4}\left(\mathrm{BF}_{4}\right)\left(\mathrm{H}_{2} \mathrm{O}\right)\right]$ and $\left[\mathrm{Ru}_{2}(\mathrm{HNOCPh})_{4} \mathrm{Cl}\right]_{n}$ have a quartet ground state, the electronic structure of which, $\pi^{4} \sigma^{2} \delta^{2} \pi^{* 2} \delta^{* 1}$, was demonstrated by DFT calculations. $\mathrm{The}_{\mathrm{Ru}_{2}}{ }^{6+} / \mathrm{Ru}_{2}{ }^{5+}$ redox couple was observed at $1.12 \mathrm{~V}$ (vs. SCE) for $\left[\mathrm{Ru}_{2}(\mathrm{HNOCPh})_{4}\left(\mathrm{BF}_{4}\right)\left(\mathrm{H}_{2} \mathrm{O}\right)\right]$ in dichloromethane containing $\mathrm{Bu}_{4} \mathrm{NPF}_{6}$ as electrolyte.

Supplementary Materials: The following are available at http://www.mdpi.com/2312-7481/4/2/21/s1. Selected bond distance and angles (Table S1) and hydrogen-bonding network in the crystal for $\left[\mathrm{Ru}_{2}(\mathrm{HNOCPh})_{4}\left(\mathrm{BF}_{4}\right)\left(\mathrm{H}_{2} \mathrm{O}\right)\right] \cdot 2$ (acetone) (Figure S1).

Author Contributions: M.H. conceived and designed the experiment, analyzed the data and wrote the paper; N.Y., A.O. and H.N. performed the experiments. Minoru Mitsumi helped the SQUID measurements and X-ray crystal structure determination. Masahiro Mikuriya measured diffuse reflectance spectra. Y.K. measured SQUID, determined X-ray crystal structure, performed DFT calculation and wrote the part of DFT calculation results in the paper.

Acknowledgments: The present work was partially supported by Grants-in-Aid for Scientific Research Nos. 15K17897, 16K05722 and 17K05820 from the Ministry of Education, Culture, Sports, Science and Technology (MEXT), Japan. N.Y. acknowledges Research Fellowships of Japan Society for the Promotion of Science for Young Scientists. The authors are grateful to Michiko Egawa (Shimane University) for her measurements of elemental analyses.

Conflicts of Interest: The authors declare no conflict of interest.

\section{References}

1. Cotton, F.A.; Murillo, C.A.; Walton, R.A. Multiple Bonds between Metal Atoms, 3rd ed.; Springer: New York, NY, USA, 2005.

2. Liddle, S.T. Molecular Metal-Metal Bonds, Compounds, Synthesis, Properties; Wiley-VCH: Weinheim, Germany, 2015.

3. Aquino, M.A.S. Diruthenium and diosmium tetracarboxylates: Synthesis, physical properties and applications. Coord. Chem. Rev. 1998, 170, 141-202. [CrossRef]

4. Aquino, M.A.S. Recent developments in the synthesis and properties of diruthnium tetracarboxylates. Coord. Chem. Rev. 2004, 248, 1025-1045. [CrossRef]

5. Mikuriya, M.; Yoshioka, D.; Handa, M. Magnetic interactions in one-, two-, and three-dimensional assemblies of dinuclear ruthenium carboxylates. Coord. Chem. Rev. 2006, 250, 2194-2211. [CrossRef]

6. Cotton, F.A.; Ren, T. Preparation and Properties of $\mathrm{Ru}_{2}(\mathrm{DtolF})_{4} \mathrm{Cl}$ : A Surprosing Electronic Structure Change Compared to $\mathrm{Ru}_{2}(\mathrm{DtolF})_{4}\left(\mathrm{DtolF}=[(p \text {-tol)NCHN( } p \text {-tol })]^{-}\right)$. Inorg. Chem. 1995, 34, 3190-3193. [CrossRef]

7. Chen, W.-Z.; Cotton, F.A.; Dalal, N.S.; Murillo, C.A.; Ramsey, C.M.; Ren, T.; Wang, X. Proof of Large Positive Zero-Field Splitting in a $\mathrm{Ru}_{2}{ }^{5+}$ Paddlewheel. J. Am. Chem. Soc. 2005, 127, 12691-12696. [CrossRef] [PubMed]

8. Barral, M.C.; Gallo, T.; Herrero, S.; Jiménez-Aparicio, R.; Torres, M.R.; Urbanos, F.A. The First Open-Paddlewheel Structures in Diruthenium Chemistry: Examples of Intermediate Magnetic Behaviour between Low and High Spin in $\mathrm{Ru}_{2}{ }^{5+}$ species. Chem. Eur. J. 2007, 13, 10088. [CrossRef] [PubMed]

9. Angaridis, P.; Cotton, F.A.; Murillo, C.A.; Villagrán, D.; Wang, X. Structural and Magnetic Evidnece Concerning Spin Crossover in Formamidinate Compounds with $\mathrm{Ru}_{2}{ }^{5+}$ Cores. J. Am. Chem. Soc. 2005, 127, 5008-5009. [CrossRef] [PubMed]

10. Chiarella, G.M.; Cotton, F.A.; Murillo, C.A.; Ventura, K.; Villagrán, D.; Wang, X. Manipulating Magnetism: $\mathrm{Ru}_{2}{ }^{5+}$ Paddlewheels Devoid of Axial Interactions. J. Am. Chem. Soc. 2014, 136, 9580-9589. [CrossRef] [PubMed]

11. Malinski, T.; Chang, D.; Feldmann, F.N.; Bear, J.L.; Kadish, K.M. Electrochmical Studies of a Novel Ruthenium(II,III) Dimer, $\mathrm{Ru}_{2}\left(\mathrm{HNOCCF}_{3}\right)_{4} \mathrm{Cl}$. Inorg. Chem. 1983, 22, 3225-3233. [CrossRef]

12. Kadish, K.M.; Lancon, D.; Cocolios, P.; Guilard, R. Electrochemical Generation of New Dinuclear Ruthenium Acetamidate Complexes. Inorg. Chem. 1984, 23, 2373-2375. [CrossRef]

13. Chakravarty, A.R.; Cotton, F.A.; Tocher, D.A. Displative Transfer of a Phenyl Group from Triphenylphosphine to a Metal Atom: Synthesis and Molecular Structure of $\mathrm{Ru}_{2} \mathrm{Ph}_{2}(\mathrm{PhCONH})_{2}\left[\mathrm{Ph}{ }_{2} \mathrm{POC}(\mathrm{Ph}) \mathrm{N}_{2}\right.$. J. Am. Chem. Soc. 1984, 106, 6409-6413. [CrossRef] 
14. Chakravarty, A.R.; Cotton, F.A.; Tocher, D.A. Synthesis and Structure of a Binuclear Ruthenium 4-Chlorobenzoamidato Complex. Polyhedron 1985, 4, 1097-1102. [CrossRef]

15. Chakravarty, A.R.; Cotton, F.A. Structure of a Diruthenium(II,III) Complex with Benzoato Bridging Ligands. Polyhedron 1985, 4, 1957-1958. [CrossRef]

16. Barral, M.C.; Jiménez-Aparicio, R.; Priego, J.L.; Royer, E.C.; Urbanos, F.A.; Monge, A.; Ruíz-Valero, C. Tert-butylbenzamidate Diruthenium(II,III) Compounds. Crystal Structure of $\left[\mathrm{Ru}_{2}\left(\mu-\mathrm{HNOC}_{6} \mathrm{H}_{4}-p-\mathrm{CMe}_{3}\right)_{4}\left(\mathrm{OPPh}_{3}\right)_{2}\right] \mathrm{BF}_{4}$. Polyhedron 1993, 12, 2947-2953. [CrossRef]

17. Barral, M.C.; de la Fuente, I.; Jiménez-Aparicio, R.; Priego, J.L.; Torres, M.R. Synthesis of diruthenium(II,III) amidate compounds. Crystal Structure of $\left[\mathrm{Ru}_{2}\left(\mu-\mathrm{HNOCC}_{4} \mathrm{H}_{3} \mathrm{~S}\right)_{4}(\mathrm{thf})_{2}\right] \mathrm{SbF}_{6} \cdot 0.5$ cyclohexane. Polyhedron 2001, 20, 2537-2544. [CrossRef]

18. Villalobos, L.; Cao, Z.; Fanwick, P.E.; Ren, T. Diruthenium(II,III) tetraamidates as new class of oxygenation catalysts. Dalton Trans. 2012, 41, 644-650. [CrossRef] [PubMed]

19. Delgado, P.; González-Prieto, R.; Jiménez-Aparicio, R.; Perles, J.; Priego, J.L.; Torres, R.M. Comparative study of different methods for the preparation of tetraamidato- and tetracarboxylatodiruthenium compounds. Structural and magnetic characterization. Dalton Trans. 2012, 41, 11866-11874. [CrossRef] [PubMed]

20. Delgado-Martinez, P.; GonzEalez-Prieto, R.; Gómez-García, C.J.; Jiménez-Aparicio, R.; Priego, J.L.; Torres, M.R. Structural, magnetic and electrical properties of one-dimensional tetraamidatodiruthnium compounds. Dalton Trans. 2014, 43, 3227-3237. [CrossRef] [PubMed]

21. Delgado-Martínez, P.; Freire, C.; Conzález-Prieto, R.; Jiménez-Aparicio, R.; Priego, J.L.; Torres, M.R. Synthesis, Crystal Structuyre, and Magnetic Properties of Amidate and Carboxylate Dimers of Ruthenium. Crystals 2017, 7, 192. [CrossRef]

22. Nakamoto, K. Infrared and Raman Spectra, 4th ed.; John Wile \& Sons: New York, NY, USA, 1986.

23. Kataoka, Y.; Mikami, S.; Sakiyama, H.; Mitsumi, M.; Kawamoto, T.; Handa, M. A neutral paddlewheel-type diruthenium(III) complex with benzamidinato ligands: Synthesis, crystal structure, magnetism, and electrochemical and absorption properties. Polyhedron 2017, 136, 87-92. [CrossRef]

24. Xu, G.-L.; Jablonski, C.G.; Ren, T. $\mathrm{Ru}_{2}(\mathrm{DMBA})_{4}\left(\mathrm{BF}_{4}\right)_{2}$ and $\mathrm{Ru}_{2}(\mathrm{DMBA})_{4}\left(\mathrm{NO}_{3}\right)_{3}$ : The first exapmles of diruthenium compounds containg $\mathrm{BF}_{4}{ }^{-}$and $\mathrm{NO}_{3}{ }^{-}$as Ligands. Inorg. Chim. Acta 2003, 343, 387-390. [CrossRef]

25. Corcos, A.R.; Berry, J.F. Anilinpyridinate-supported $\mathrm{Ru}_{2}{ }^{\mathrm{X}+}(\mathrm{x}=5$ or 6$)$ paddlewheel complexes with labile axial ligands. Dalton Trans. 2017, 46, 5532-5539. [CrossRef] [PubMed]

26. Fuma, Y.; Ebihara, M. Tetra- $\mu$-acetamidati- ${ }^{4} N: O ; \kappa^{4} O: N$-bis[aquaruthenium(II,III)] $(R u$ - $R u)$ perchlorate. Acta Crstallogr. Sect. E 2006, 62, m2802-m2804. [CrossRef]

27. Fuma, Y.; Ebihara, M. Tetra- $\mu$-acetamidati- $\kappa^{4} N: O ; \kappa^{4} O: N-b i s[a q u a r u t h e n i u m(I I, I I I)](R u-R u)$ nitrate. Acta Crstallogr. Sect. E 2006, 62, m2805-m2807. [CrossRef]

28. Fuma, Y.; Ebihara, M. Tetra- $\mu$-acetamidati- $\kappa^{4} N: O ; \kappa^{4} O: N$-bis[aquaruthenium(II,III)](Ru-Ru) tetraphenylborate monohydrate. Acta Crstallogr. Sect. E 2006, 62, m2808-m2810. [CrossRef]

29. Telser, J.; Drago, R.S. Reinvesigation of the Electronic and Magnetic Properties of Ruthenium Butyrate Chloride. Inorg. Chem. 1984, 23, 3114. [CrossRef]

30. Telser, J.; Drago, R.S. Correction: Reinvesigation of the Electronic and Magnetic Properties of Ruthenium Butyrate Chloride. Inorg. Chem. 1985, 24, 4765. [CrossRef]

31. O'Connor, C.J. Magnetochemistry-Advances in Theory and Experimentaion. Prog. Inorg. Chem. 1982, 29, 203. [CrossRef]

32. Hiraoka, Y.; Ikeue, T.; Sakiyama, H.; Gúgan, F.; Luneau, D.; Gillon, B.; Hiromitsu, I.; Yoshioka, D.; Mikuriya, M.; Kataoka, Y.; et al. An unprecedented up-field shift in the ${ }^{13} \mathrm{C}$ NMR spectrum of the carboxyl carbons of the lantern-type dinuclear complex TBA $\left[\mathrm{Ru}_{2}\left(\mathrm{O}_{2} \mathrm{CCH}_{3}\right)_{4} \mathrm{Cl}_{2}\right]\left(\mathrm{TBA}^{+}=\right.$tetra(n-butyl)ammonium cation. Dalton Trans. 2015, 44, 13439-13443. [CrossRef] [PubMed]

33. Stephenson, T.A.; Wilkinson, G. New ruthenium carboxylate complexes. J. Inorg. Nucl. Chem. 1966, $28,2285$. [CrossRef]

34. Kahn, O. Molecular Magnetism; VCH: Cambridge, UK, 1993; Chapter 1.

(C) 2018 by the authors. Licensee MDPI, Basel, Switzerland. This article is an open access article distributed under the terms and conditions of the Creative Commons Attribution (CC BY) license (http:/ / creativecommons.org/licenses/by/4.0/). 